\title{
Synthesis and structural-chemical studies of hexoaquatribenzene- 1, 2, 4, 5- tetracarbon-tetrairon (III) coordinator compound
}

\author{
Usubaliev BT ${ }^{1}$, Tagiyev DB ${ }^{1}$, Nurullayev VH ${ }^{1 *}$, Munshieva MK ${ }^{1}$, Aliyeva FB ${ }^{2}$, Hasanova MM¹, Rzayeva AQ ${ }^{1}$ and Safarova PS ${ }^{2}$ \\ ${ }^{1}$ Azerbaijani State University Oil and Industry Research Institute "Geotechnological problems of oil, gas and chemistry" Azerbaijan \\ ${ }^{2}$ Institute of Catalysis and Inorganic Chemistry named after MF. Nagiyev National Academy of Sciences of Azerbaijan
}

\begin{abstract}
Iron (III) benzene-1, 2, 4, 5-tetracarbonyl acid complex compounds with a porous structure was first synthesized. As a result of the element, X-ray diffraction, infrared spectroscopy and differential thermal analyses, revealed individuality, the chemical formula of a complex compound and the acid anion form of coordination was determined; the process of thermal degradation of the resulting compound was studied as well. By identification of diffractograms, the parameters of the unit cell of the complex compound are determined and considered that it has a three-dimensional porous branched-layered structure.
\end{abstract}

\section{Introduction}

Previously we have synthesized complex compounds of copper, zinc and iron (II) benzene-1,2,4,5-tetracarbonyl acid [1-7]. Basing on them we decrypted crystal structure of the complex compound [1].

The crystal structure has a porous-layered structure. The structure of the complex compound includes ten crystallized molecules of water, eight of which are included in the coordination of the central atom. The remaining two water molecules are not coordinating and participate in the formation of intra and intermolecular hydrogen bonds.

Due to their layered structures, they can be used as molecular sieves and adsorbents, and on their basis a number of non-bonded selfassembled compounds can be obtained.

This paper presents the results of the synthesis, physico-chemical and structural studies of complex compounds hexoaquatribenzene1,2,4,5-tetracarbon-tetrairon (III). Preliminary research has shown that it improves the rheological properties of oils and oil deposits.

\section{Experimental part}

Gas chromatography analyzer $\mathrm{CHN}_{3} \mathrm{OE}$ Carlo ERBA determined the elemental composition of the obtained compound. The metal content was calculated from TG curve (weight loss) by the number of oxide obtained after heating to derivatograph $800^{\circ} \mathrm{C}$.

$\mathrm{X}$-ray diffraction analysis was performed on the unit Commander Sample ID (Coupled Two Thet|Theta) WL/1.54060.

IR spectra were recorded on the device SPECORD-MBO in a range of $400-4000 \mathrm{~cm}^{1}$.

Derivatograms recorded on derivatograf NETZCH STA 449F3 STA 449F3A-0836-M (Range 20/10.0 (K/min)/800).

Synthesis of the compound: The starting materials were $\mathrm{C}_{6} \mathrm{H}_{2}(\mathrm{COOH})_{4}$ (pyromellitic acid), $\mathrm{FeCI}_{3} \cdot 7 \mathrm{H}_{2} \mathrm{O} \cdot \mathrm{NaHCO}_{3}$ qualification
ChC (GOST 3759-75). Synthesis of complex compound was carried out in two stages. In the first stage, the sodium salt of pyromellitic acid was obtained at a stoichiometric ratio $\mathrm{C}_{6} \mathrm{H}_{2}(\mathrm{COOH})_{4}: \mathrm{NaHCO}_{3}=1: 4$.

To carry out the synthesis we took $0,762 \mathrm{~g}(0,003 \mathrm{~mol})$ pyromellitic acid and $100 \mathrm{ml}$ of distilled water and then added portion wise $1,344 \mathrm{~g}(0.0012 \mathrm{~mol})$ by heating with sodium bicarbonate powder. After complete dissolution of the acid was added a solution of $0.79 \mathrm{~g}$ $(0,004 \mathrm{~mol}) \mathrm{FeCI}_{3} \cdot 7 \mathrm{H}_{2} \mathrm{O}$ and heated to a boil, then cooled to room temperature.

In the reaction with the sodium salt of the acid chloride, iron (III) precipitates abundantly fine dense polycrystalline powder of a dark brown color. The powder was filtered hot and washed with distilled water several times, first on the filter paper was dried at room temperature and then in an oven at $500^{\circ} \mathrm{C}$. The chemical formula of complex compounds established based on the results of X-ray diffraction (XRD), Elemental, thermogravimetric (TGM) and infrared spectroscopic analysis.

\section{Discussion}

Elemental analysis: The elemental composition of the synthesized compounds is shown in table 1 .

According to the results of elemental analysis for the obtained compound of chemical formula can be written as $\mathrm{Fe}_{4}\left(\mathrm{C}_{6} \mathrm{H}_{2}(\mathrm{COO})_{4}\right)_{3}\left(\mathrm{H}_{2} \mathrm{O}\right)_{6}$.

Correspondence to: Veli Nurullaev, Azerbaijani State University Oil and Industry Research Institute "Geotechnological problems of oil, gas and chemistry" Azerbaijan, AZ 1010, Baku, D.Aliyeva str, 227; Tel: (99412) 4314064; E-mail: veliehet1973@mail.ru

Key words: complex compound, unit cell, pyromellitic acid, thermal destruction, chemical formula, crystalline structure, IR-spectrum

Received: June 25, 2017; Accepted: July 26, 2017; Published: July 29, 2017 
X-ray diffraction analysis: The XRD pattern of the synthesized product is provided in Figure 1. As seen from the X-ray data, the obtained product is not very crystalline, but has clear peaks that are located in all corners of the diffraction pattern. All peaks are fully identified by means: $10.33 ; 15.92 ; 11.21$, which indicated that the product consists of one phase and the unit cell parameters of the compound conventionally comprise $-\mathrm{a}=10,33, \mathrm{~b}=15,92$ and $\mathrm{c}=11,21 \AA$.

Comparison of the parameters of the unit cell of this compound with the parameters of the unit cells of known systems in this series showed that they are not isostructural and isomorphic (table 2).

\section{IR-spectroscopic analysis}

IR-spectrum of the complex compound is shown in Figure 2. As seen from the figure, in the spectrum range of $3600-3200 \mathrm{~cm}^{-1}$, particularly in 3200 and $3377 \mathrm{~cm}^{-1}$, there is a broad absorption band, which relates to the asymmetric and symmetric vibrations of $\mathrm{OH}$ groups of water molecules $[8,9]$. Separation $\mathrm{OH}$ absorption bands of water indicates that they are in different positions in the structure.

Absorption bands at $1575 \mathrm{~cm}^{-1}\left(v_{\mathrm{a}}\right)$ and $1377 \mathrm{~cm}^{-1}\left(v_{\mathrm{s}}\right)$ in the spectrum are related to Frequencies of the valence vibrations of the carboxyl group $(\mathrm{C}=\mathrm{O})$ and $(\mathrm{C}-\mathrm{O})$ pyromellitic acid anion accordingly. This shows that they are linked to the central atom of the same type. A difference of value $\Delta=\left[v_{2}\left(\mathrm{CO}_{2}\right)-v_{\mathrm{s}}\left(\mathrm{CO}_{2}^{-}\right)\right] 198 \mathrm{~cm}^{-1}$ is much greater than that of ionic complexes $\left(\sim 164 \mathrm{~cm}^{-1}\right)$, so we can confidently say that in this complex carboxylate groups are linked with metal mono dentate.

\section{Thermogravimetric analysis}

Termogravigramm complex compound is shown in Figure 3. The complex compound is stable up to $90^{\circ} \mathrm{C}$ temperature. Starting from temperature $90^{\circ} \mathrm{C}$ and in a range of temperatures up to $150^{\circ} \mathrm{C}$, a clear shallow endotherm appears at $142^{\circ} \mathrm{Cmaximum}$, which corresponds to four molecules of water removal. In this case the experimental mass loss is of $6.5 \%$ (calculated $6.65 \%$ ). Immediately thereafter, the DTG curve appears at another fuzzy shallow endotherm in the temperature range of $150^{\circ} \mathrm{C}-220^{\circ} \mathrm{C}$, with a maximum at $180^{\circ} \mathrm{C}$, which also corresponds to two molecules of water removal. At this stage, the mass decrease was $3.5 \%$ (calculated 3.3\%).

The complex compound is stable up to $90^{\circ} \mathrm{C}$ temperature. Starting from temperature $90^{\circ} \mathrm{C}$ and in a range of temperatures up to $150^{\circ} \mathrm{C}$, a clear shallow endotherm appears at $142^{\circ} \mathrm{Cmaximum}$, which corresponds to four molecules of water removal. In this case the experimental mass loss is of $6.5 \%$ (calculated 6.65\%). Immediately thereafter, the DTG curve appears at another fuzzy shallow endotherm in the temperature range of $150^{\circ} \mathrm{C}-220^{\circ} \mathrm{C}$, with a maximum at $180^{\circ} \mathrm{C}$, which also corresponds to two molecules of water removal. At this stage, the mass decrease was 3.5\% (calculated 3.3\%). As can be seen, the various $\mathrm{OH}$ absorption bands of water molecules in the infrared spectrum and gradual water removal at a thermal destruction of the complex compound complement results of two analyzes. From these results it can be concluded that, despite of the fact, that the temperature

Table 1. Results of elemental analysis of the resulting product.

\begin{tabular}{|c|c|c|c|c|c|c|}
\hline \multicolumn{3}{|c|}{ Find, \% } & \multirow{2}{*}{ Chemical composition } & \multicolumn{3}{|c|}{ Calculated, \% } \\
\cline { 5 - 7 } & $\mathrm{Ce}$ & $\mathrm{Fe}$ & $\mathrm{C}$ & $\mathrm{H}$ \\
\hline $\mathrm{H}$ & $\mathrm{C}$ & $\mathrm{Fe}$ & $\mathrm{Fe}_{4} \mathrm{C}_{30} \mathrm{H}_{18} \mathrm{O}_{30}$ & 20,70 & 33,27 & 1,66 \\
\hline
\end{tabular}

Table 2. Comparison of the parameters of the unit cell with parameters of known systems

\begin{tabular}{|c|c|c|c|c|c|}
\hline Complex equations & $\boldsymbol{a}, \mathbf{A}^{\circ}$ & $\boldsymbol{6}, \mathbf{A}^{\circ}$ & $\boldsymbol{c}, \mathbf{A}^{\circ}$ & $\begin{array}{c}\text { Molecule } \\
\text { weight }\end{array}$ & Literature \\
\hline $\mathrm{Cu}_{2}\left(\mathrm{C}_{6} \mathrm{H}_{2}(\mathrm{COO})_{4}\right) \cdot 10 \mathrm{H}_{2} \mathrm{O}$ & 9,679 & 18,17 & 12,18 & 557,36 & {$[1]$} \\
\hline $\mathrm{Cu}_{2}\left(\mathrm{C}_{6} \mathrm{H}_{2}(\mathrm{COO})_{4}\right) \cdot 2 \mathrm{H}_{2} \mathrm{O}$ & 10,68 & 19,11 & 11,28 & 413,24 & {$[2]$} \\
\hline $\mathrm{Zn}_{2}\left(\mathrm{C}_{6} \mathrm{H}_{2}(\mathrm{COO})_{4}\right) \cdot 4 \mathrm{H}_{2} \mathrm{O}$ & 9,78 & 19,70 & 11,76 & 452,92 & {$[3]$} \\
\hline $\mathrm{Fe}_{2}\left(\mathrm{C}_{6} \mathrm{H}_{2}(\mathrm{COO})_{4}\right) \cdot 6 \mathrm{H}_{2} \mathrm{O}$ & 10,10 & 18,24 & 11,76 & 469,90 & {$[4]$} \\
\hline $\mathrm{Fe}_{4}\left(\mathrm{C}_{6} \mathrm{H}_{2}(\mathrm{COO})_{4}\right)_{3} \cdot 6 \mathrm{H}_{2} \mathrm{O}$ & 10,33 & 15,92 & 11,21 & 1081,55 & \\
\hline
\end{tabular}

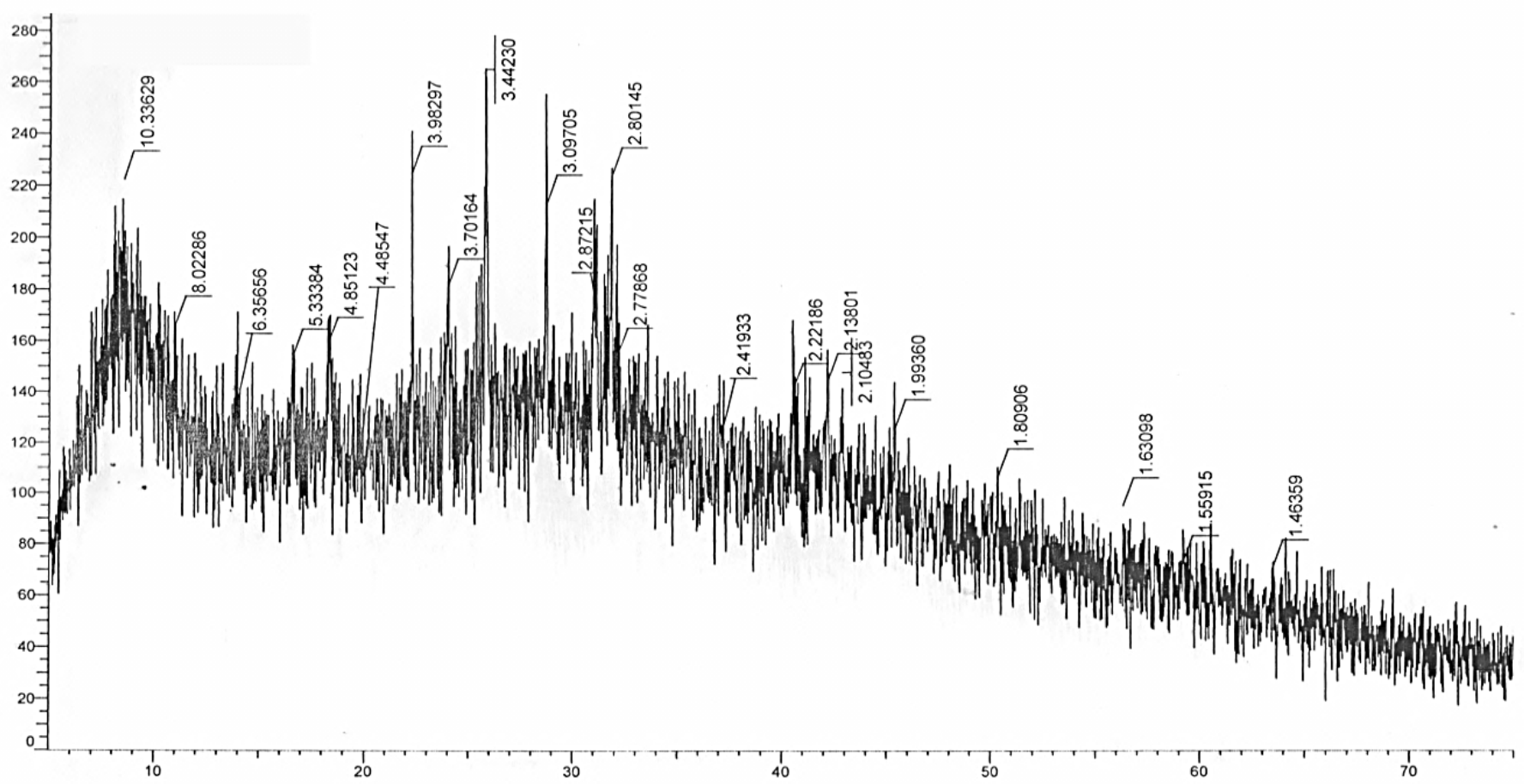

Figure 1. XRD of the synthesized complex of iron (III) 


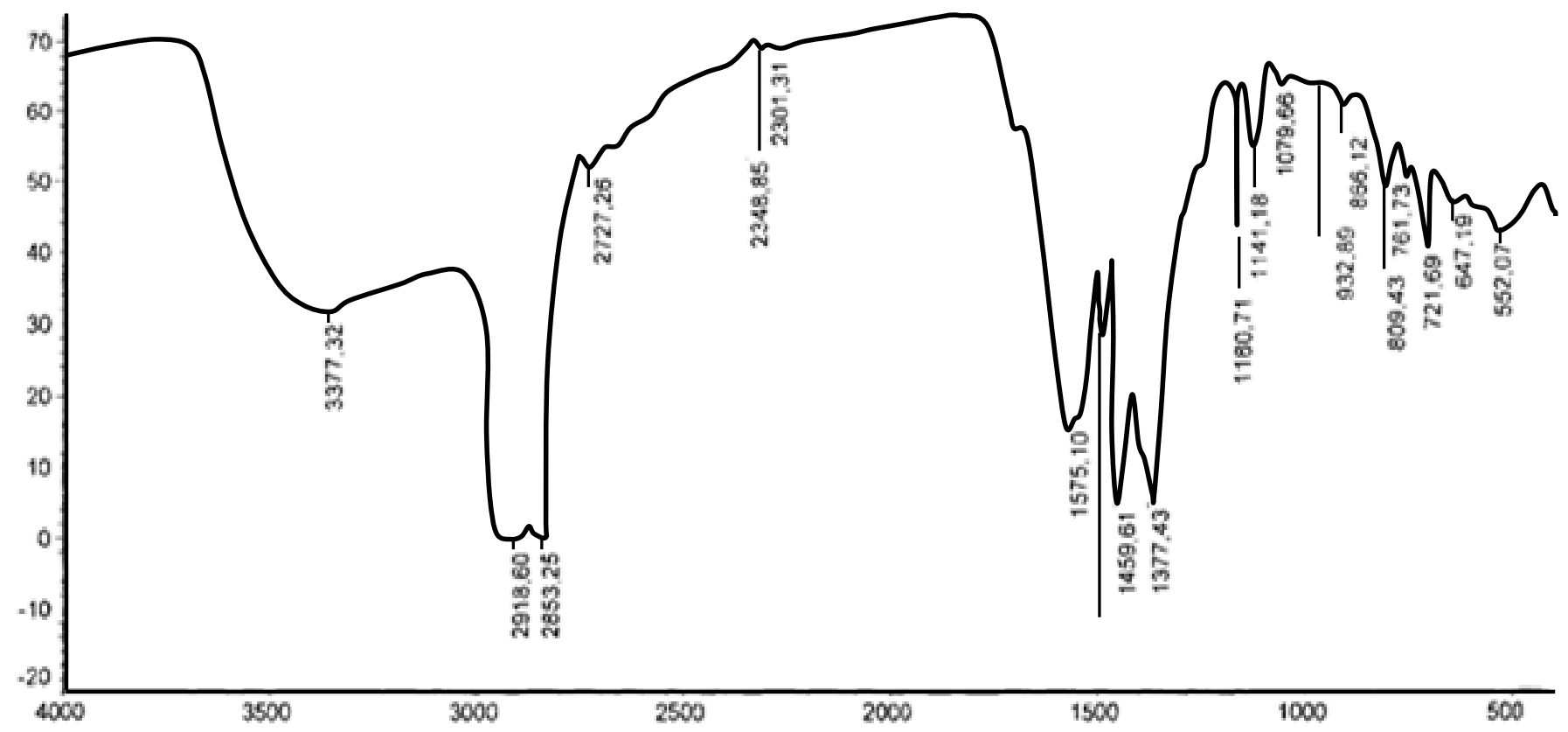

Figure 2. IR-spectrum of the complex compound of iron (III).

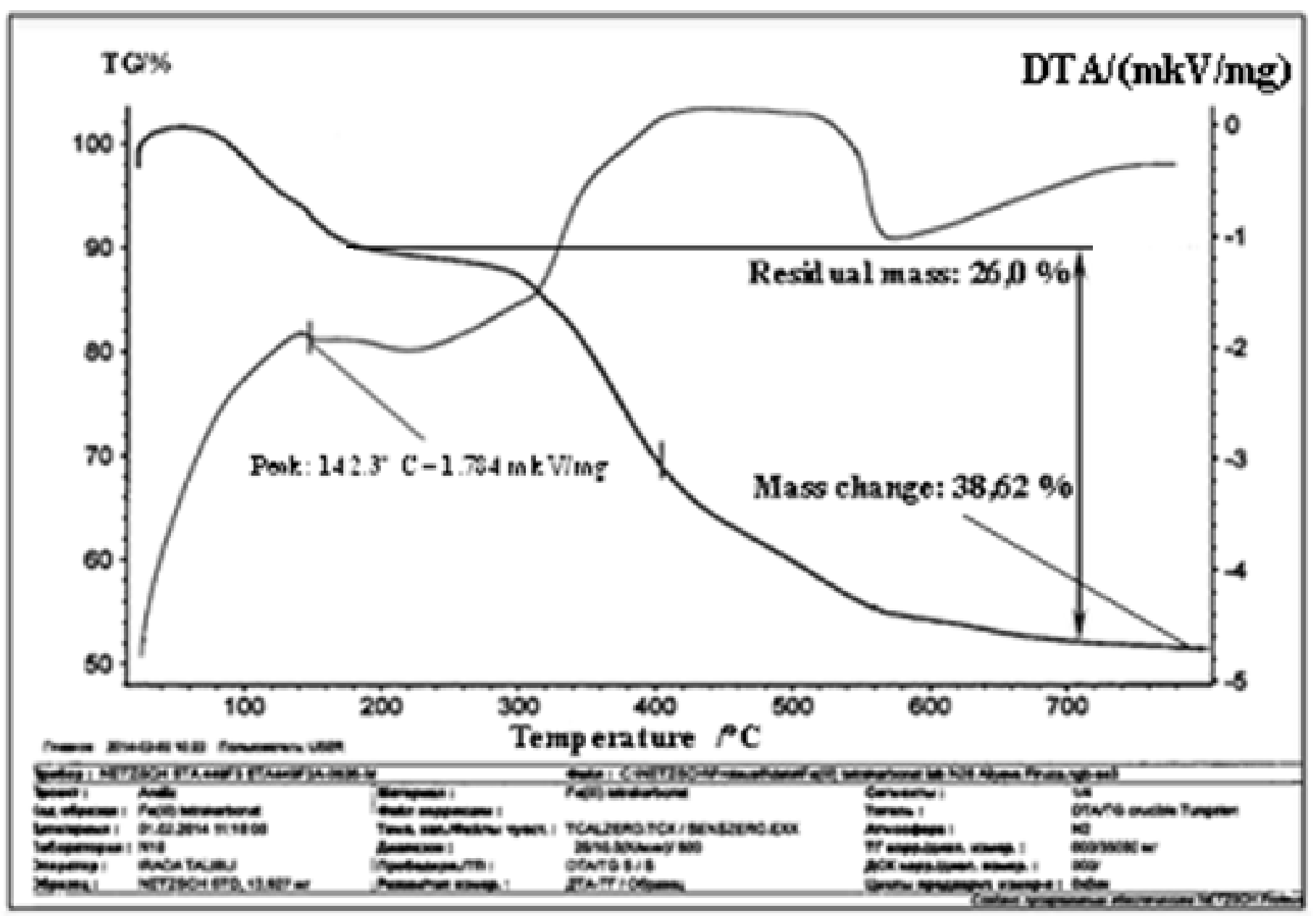

Figure 3. Termogravigramm complex compound of iron (III). 
of four water molecules removal is lower than the temperature of two water molecules removal, the first of which is coordinated (4 mol). This can be explained by the fact that each metal atom requires one molecule of water. If carboxyl groups are monodental and one water molecule is part of the metal coordination, the metal coordination number is 4 (planar), that corresponds to Fe(III). In our opinion, low temperature of coordination-bound water molecules removal is related to the spatial factor. After water removal, the anhydrous complex compound is stable to temperatures up to $290^{\circ} \mathrm{C}$. Starting from temperature over $290^{\circ} \mathrm{C}$ in a wide temperature range of $290-798^{\circ} \mathrm{C}$, anhydrous compound gradually decomposes and the burnout of the organic part of a molecule occurs. These processes are accompanied by a broad exothermic effect peaking at $420^{\circ} \mathrm{C}$ and $450^{\circ} \mathrm{C}$. In this case the experimental weight loss was $38.62 \%$ (calculated $36.037 \%$ ) and the final product is $2 \mathrm{Fe}_{2}\left(\mathrm{CO}_{3}\right)_{3}$. The experimental weight loss during this was $51.38 \%$ (calculated $53.99 \%$ ).

According to studies the formula of the complex compound was established $\left[\mathrm{Fe}_{4}\left(\mathrm{C}_{6} \mathrm{H}_{2}(\mathrm{COO})_{4}\right)_{3}\left(\mathrm{H}_{2} \mathrm{O}\right)_{4}\right]\left(\mathrm{H}_{2} \mathrm{O}\right)_{2}$.

The scheme of a solid phase transformation of a complex compound is given below:

$$
\begin{array}{cll}
{\left[\mathrm{Fe}_{4}\left(\mathrm{C}_{6} \mathrm{H}_{2}(\mathrm{COO})_{4}\right)_{3}\left(\mathrm{H}_{2} \mathrm{O}\right)_{4}\right]\left(\mathrm{H}_{2} \mathrm{O}\right)_{2}} & \frac{90-150\left(142^{\circ} \mathrm{C}\right)}{-4 \mathrm{H}_{2} \mathrm{O}} \mathrm{Fe}_{4}\left(\mathrm{C}_{6} \mathrm{H}_{2}(\mathrm{COO})_{4}\right)_{3}\left(\mathrm{H}_{2} \mathrm{O}\right)_{2} \\
\hline 150-220\left(180^{\circ} \mathrm{C}\right) & \mathrm{Fe}_{4}\left(\mathrm{C}_{6} \mathrm{H}_{2}(\mathrm{COO})_{4}\right)_{3} & \frac{290-798\left(480^{\circ} \mathrm{C}\right)}{-2 \mathrm{H}_{2} \mathrm{O}} 2 \mathrm{Fe}_{2}\left(\mathrm{CO}_{3}\right)_{3}
\end{array}
$$

Thus, the coordination number of the iron (III) complex corresponds to 6 and coordination polyhedron - is a distorted octahedron. The coordination of the metal ion includes five oxygen atoms of three carboxyl groups and one oxygen atom of the water

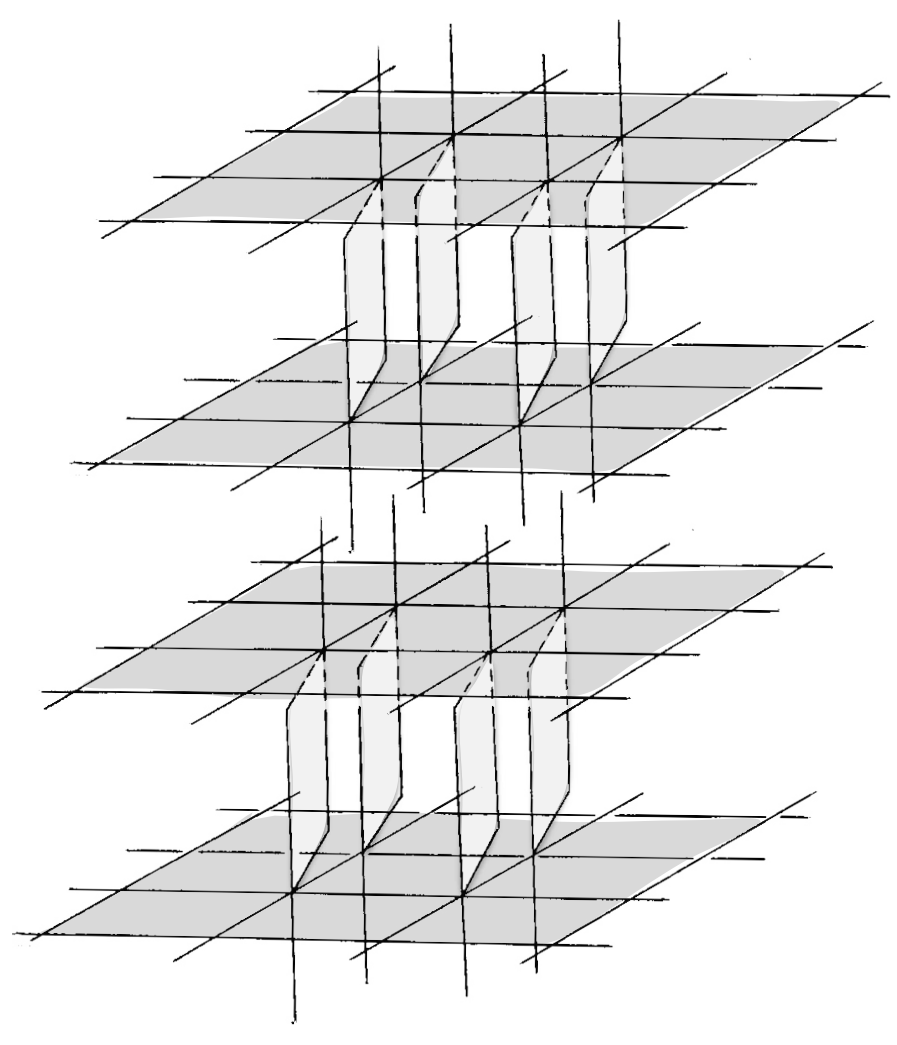

Figure 4. Alleged schematic structure of the complex of iron (III). molecule. Two of the three carboxyl groups occupy the equatorial position, and are connected with a metal chelate, and a third anion occupies an axial position and acts as a bridge between the layers and monodentate. Besides, the second axial positions by oxygen and water molecules are formed dimer-dimensional force. A two-dimensional dimer layers are stitched together by hydrogen bonds with two water molecules, which are not included in the coordination of the central atom. Thus, 2D structure transforms into 3D structure. Estimated schematic structure of the coordination compound is shown in Figure 4.

\section{Acknowledgement}

This work was supported by the Science Development Fund under the President of Azerbaijan Republic, Grant No. EIF/GAM-3-2014-6 (21)-24/09/4.

\section{References}

1. Usubaliev BT, Shnulin AN, Mamedov HS (1982) Kristallicheskaja i mole-kuljarnaja struktura dekagidratnogo kompleksa medi s 1,2,4,5-benzaltetrakarbo-novoj kislotoj. Koordinacionnaja himija. 8: 1532-1538.

2. Usubaliev BT, Munshieva MK, Alieva FB (2016) i dr. Sintez i issle-dovanie fizikihimicheskih svojstv i struktur (diakva(benzol-1,2,4,5-tetra-karboksilata dimedi (II). Zhurnal obshhej himii. 86: 89-91.

3. Usubaliyev BT, Munshiyeva MK, Nurullayev VH (2016) Syuthtsis, Physi-cal and Strukture-Chemical of Research of Coordinating compounds of Diaquo-1,2,4,5Benzoltetracarbonat Dikopper (II). Bylletin of Environment, Pharmacology and life Sciences. 5: 12-17.

4. Usubaliyev BT, Nurullayev VH, Aliyeva FB (2016) Synthesis and StructuralChemical of Research of Coordinating compounds of Tetraaqua Bisbenzol-1,2,4,5Tetracarboksilat Dixyin (II). Bull Pharmacology and life Scienses. 5: 10-16.

5. Usubaliyev BT, Taghiyev DB, Nurullayev VH (2017) Structural and Chemical of Research of Coordination Compounds of Hexaaqua- Bisbenzol-1,2,4,5-Tetracarbonate Diiron (II) with a Layered-Porous Structure. J Nanomater Mol Nanotechnol. 6: 2-5.

6. Usubaliyev BT, Taghiyev DB, Nurullayev VH (2017) Structural and Chemical of Research of Coordination Compounds of Hexaaqua-bisbenzol-1,2,4,5-Tetracarbonate Diiron (II) with a Layered-Porous Structure, For Heavy Crude Oil. International Journal of Nanj Studies and Technology. 6: 123-127.

7. Usubaliyev BT, Taghiyev DB, Nurullayev VH, Aliyeva FB, Munshiyeva MK, et al (2017) Structural and Chemical of Research of Coordinating compounds of HexaaquaBisbenzol-1,2,4,5-Tetracarbonate Diiron (II) with a Layered-Porous Structure. $J$ Nanomater Mol Nanotechnol, 6: 1-6.

8. Bellami L (1971) Novye dannye po IK-spektram slozhnyh molekul. Moskva Mir. 318.

9. Nakomoto K (1991) IK spektry i spektry KR neorganicheskih i koordina-cionnyh soedinenij. Moskva Mir. 535.
Copyright: (C2017 Usubaliev BT. This is an open-access article distributed under the terms of the Creative Commons Attribution License, which permits unrestricted use, distribution, and reproduction in any medium, provided the original author and source are credited. 